\title{
The Influence of Corporate Governance Mechanism to Earnings Management on Indonesia and China Industrial Banking
}

\author{
Prof. Dr. Euphrasia Susy Suhendra (Gunadarma University, Indonesia) \\ Dini Tri Wardani (Gunadarma University, Indonesia)
}

\begin{abstract}
The goal of this research is to evaluate the influence of managerial ownership structure, independent board of commissioners proportion, independent commissioner size, and audit committee size on earnings management in banking industry in China and Indonesia. The data used is secondary data with discretionary accrual as earnings management proxy. Data is processed and analyzed by independent samples t-test and multiple linear regression The results of this research show that there is a difference between earnings management, managerial ownership structure, proportion independent board of commissioners, board of commissioners size in banking industry in Indonesia and China, however there is no difference between Audit Committee size. The variable of managerial ownership structure in Indonesian's banking industry is negatively significant influence on earnings management, whereas in China has no influence. The variable of independent board of commissioners proportion in banking industry in Indonesia has no influence on earnings management, while negatively significant influence on China's. The variable of Board of Commissioners size in Indonesia banking industry positively significant influence on earnings management, while negatively significant influence in China. Then, the variable of Audit Committee size in Indonesia banking industry negatively significant influence on earnings management, whereas positively significant influence in China.
\end{abstract}

\section{Introduction}

Earning management is an intervention conducted by management on financial statement process to external parties, to obtain personal benefit (Rahmawati, 2006). Recently, earning management is a common phenomenon that occurs in several companies. The objective of this practice is to affect the profit rate which can occur legally and illegally. Financial statement scandals occurred in almost all areas including banking area. Financial statement scandals case in Indonesia, for example happenedd in PT Bank Lippo Tbk. The actions of lowering profit in the case of Lippo Bank financial statement double-scandal, proving that the practice of earnings management has begun to enter the banking industry. This makes the banking industry has become interesting to study because the banking industry has more stringent rules than other industries, such as banks must meet the criteria of minimum CAR. Therefore, managers have an incentive to manage earnings so that their companies can meet criteria required by the BI (Setiawati and Na'im, 2001).

Earning management also much happened in China's company. China's economic growth has attracted international investments significantly. In order to protect their investment interests on China's companies, investors institutions apply a transparent and efficient corporate governance system. However, in the past, China received criticism because of corporate governance that is less effective (Shi and Drake, 2002). To respond investor's criticism, China Securities Regulatory Commission (CSRC) has made rules and recommendations for Corporate Governance. CSRC provide conditions for listed companies to deal with Return on Equity (ROE) report on $6 \%$ for three years respectively, and the average of ROE for three years it should be not less than $10 \%$, and the most important criteria for delisted companies is to give the net loss report for three years respectively (Liu and Lu, 2007). Since China joined WTO in 2001, significant steps have been taken to improve corporate governance, especially through the amendment of corporations and securities law. Although China has made improvements to the corporate governance system in recent years, there is still much work to do in order to improve international standards.

Some related research done in China so far has focused on a particular mechanism of corporate governance. For example, Lai and Tam (2005) had researched only on influencing of the Independent Board Commissioners on earning management. Research on the effectiveness of corporate governance in protecting investors in Indonesia has also been a lot done, such as a research which is conducted by Ujiyanto and Pramuka (2007) that evaluate the influence mechanism of corporate governance: the composition of the Independent Board Commissioners, the size of the Board Commissioners and the size of the audit committee on earning management.

\section{Research Objectives}

These paper objective is evaluate the influence mechanism of corporate governance: the composition of the Independent Board Commissioners, the size of the Board Commissioners and the size of the audit committee on earning management. 


\section{Research Methodology}

The population in this research is banking companies in China at 2008-2010 which are listed on the Hong Kong Stock Exchange, and the public banking companies in Indonesia at 2007-2009 periods which is listed in Indonesia Stock Exchange (IDX).

In this research, earnings management measured through the discretionary accruals by disaccording the total accruals (TACC) and nondiscretionary accruals (NDACC). In calculating the DACC, Modified Jones model is used accordance with the results of Dechow et al.'s research (1995).

Following calculation model:

$$
\begin{aligned}
& \mathrm{TACC}_{\text {it }}=\mathrm{NI}_{\mathrm{it}}-\mathrm{OCF}_{\mathrm{it}} \\
& \mathrm{TACC}_{\mathrm{it}} / \mathrm{TA}_{\mathrm{i} . \mathrm{t}-1}=\beta_{1}\left(1 / \mathrm{TA}_{\mathrm{i} . \mathrm{t}-1}\right)+\beta_{2}\left(\Delta \mathrm{REV}_{\mathrm{it}} / \mathrm{TA}_{\mathrm{i} . \mathrm{t}-1}\right)+\beta_{3}\left(\mathrm{PPE}_{\mathrm{it}} / \mathrm{TA}_{\mathrm{i} . \mathrm{t}-1}\right) \text {. }
\end{aligned}
$$

From the regression equation above, NDACC can be calculated by entering the return coefficient $\beta$.

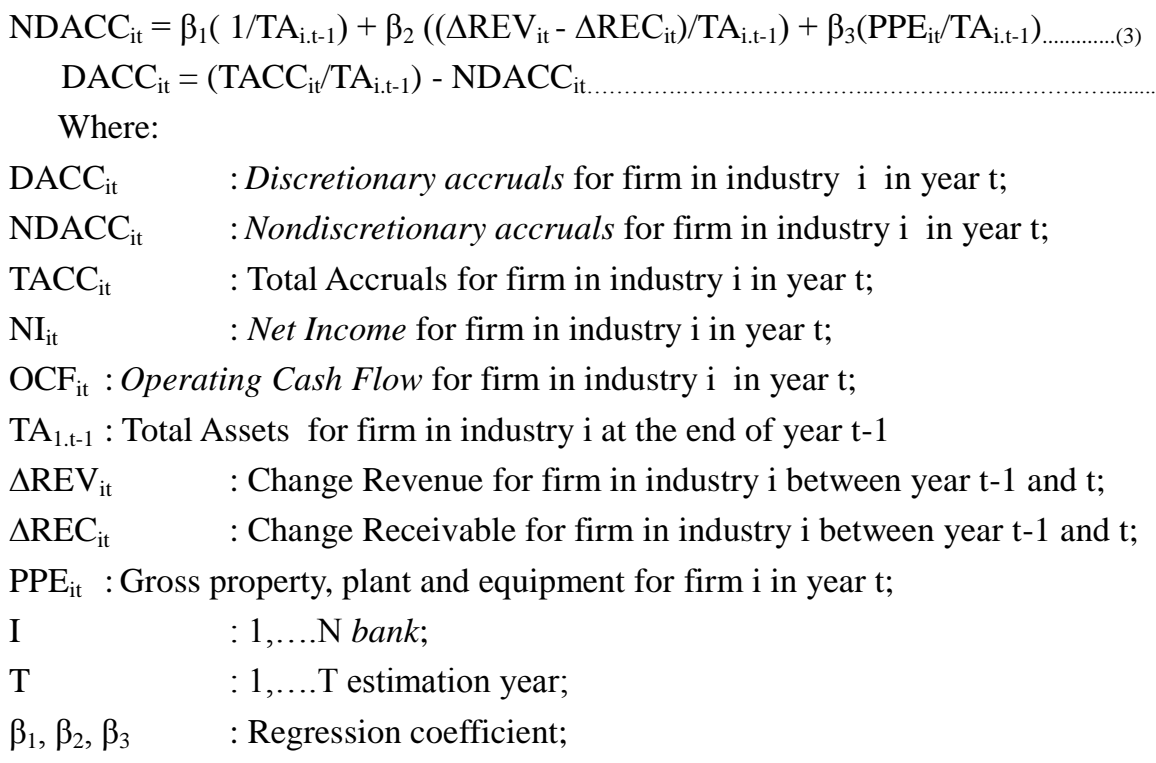

From the formula above, can be found in the absence of earnings management, then the TACC $=$ NDACC, or in other words the number of DACC $=0$.

Indicator that is used to measure the managerial ownership is percentage of the owned shares number by the management of the entire outstanding company's capital stock (Gideon, 2005).

This variable is measured using indicator of the Independent Board of Commissioners number percentage on Board of Commissioners total number of its members which is available in Company's Board of Commissioners structure (Chtourou, 2001).

Board of Commissioners size is measured using indicator of the Board of Commissioners members' number in a company (Ujiyanto \& Pramuka, 2007).

Audit Committee (AC) size is measured using indicator i.e. the total number of audit committee members, both originating from internal and from external companies.

\section{Literature And Theoretical Background}

Scott (2000) divided understanding of the earnings management into two. First, see it as opportunistic behavior of managers to maximize utility in dealing with compensation contracts, debt contracts and political costs (Profit Opportunistic Management). Second, by looking at earnings management from the perspective of efficient contracting (Efficient Profit Management), where earnings management give managers a flexibility to protect themselves and the company in order to anticipate unexpected events for the parties' benefit that get involved in the contract.

According to SFAS No. 1 accrual concept of discretionary and accrual nondiscretionary. Discretionary Accruals (DA) is an accrual that can be controlled or determined by management in which management can freely choose policies in selecting methods and estimates of accounting that will be used. Meanwhile, the NonDiscretionary accruals (NDA) is an accrual that can not be controlled or determined by management, but is determined based on economic conditions.

The separation of ownership by principal and control by agent in a company is inclined because agency conflict between principal and agents (Watts and Zimmerman, 1989). In this such conditions, required a control 
mechanism to align the differentiation between the management and principal's interest. Hence, good corporate governance is considered necessary. Komite Nasional Kebijakan Governance (KNKG, 2006) defines corporate governance as a process and structure that is used by the company in order to give add value to the company on going in the long term for shareholders, while paying attention to the stakeholders interests, based on the legislation rules and norms.

Since China joined the WTO in 2001, significant steps have been taken to improve corporate governance, especially through corporate law amendment and securities. Improvements have also given to minority shareholders positions that have been granted the authorization to organize, make movement and led the shareholders meeting. Significant progress has been done particularly to improve the governance structure in banking and equity markets. Then the hypothesis research as follows:

H1: Earnings Management in banking industry in Indonesia is different with banking industry in China.

One of the corporate governance mechanisms which are used to reduce agency cost is by increasing the ownership by management. The separation of ownership by principal and control by agents in an organization give agency conflicts between principal and agent. To minimize this conflict is by enhancing the managerial ownership in company (Siallagan and Machfoedz, 2006). From the explanation above then the hypothesis research as follows:

H2 : Managerial Ownership Structure in banking industry in Indonesia is different with banking industries' in China.

The Board Commissioners is enterprise component who are responsible collectively monitoring and providing advice to the Board Directors and ensure that enterprises carry out GCG (KNKG, 2006). To implement good corporate governance, registered companies should have mandatory independent Commissioner and the size is proportional to the number of stokes that is not owned by shareholder controller with a provision that Independent Commissioner is at least $30 \%$ of the total number of Commissioner Members. From the explanation above then the hypothesis as follow:

H3: Independent Board Commissioners' proportion in banking industry in Indonesia is different with banking industries' in China.

H4: The size of the Board Commissioners in banking industry in Indonesia is different with banking industries' in China.

The audit committee is one of the essential elements in realizing the implementation of good corporate governance. Based on Circulars IDX, SE-008/BEJ/12-2001, the membership of Audit Committee (AC) at least consists of 3 members including a Chairman of audit committee. On respect to the audit committee functions, indicated that the company that owns the audit committee has intensity of earning management activity lower than in companies that does not have audit committee. From the explanation above then the hypothesis research as follows:

H5: The size of Audit Committee in banking industry in Indonesia is different with banking industries' in China.

A wide research on corporate governance has been done with inconsistent results. One of those is research done by Midiastuty and Machfoedz (2003) the result of this research is managerial ownership and institutional ownership negatively influence on earnings management, whereas the size of Board Directors positively influence on earnings management. The analysis result Ujiyantho and Pramuka (2007) show that only managerial ownership which influence significantly to earnings management. Ding et al. (2004) analyzes show that there is no relationship between ownership shares concentration to the earnings management calculation in private enterprise, but instead in the national enterprise there is significant relationships.

Research Siallagan and Machfoedz (2006) the results prove that managerial ownership positively influence to the earnings quality, Board Commissioners negatively influence to the earnings quality, and audit committee positively influence to the earnings quality. Nasution and Setiawan (2007) was found that the proportion of independent Board Commissioners has negative influence on earnings management, size of the Board Commissioners has positive influence on earnings management, and the existence of audit committee negatively influence on earnings management.

Xie et al. (2003) the results of his research shows that audit committee from outside are able to protect the shareholders' interests from earnings management practice. The study result also found a negative relationship between the proportions of Independent Management Board Commissioner on earnings management and found a positive relationship between sizes of Board Commissioners on earnings management. Beasley (1996) concluded that the proportion of the Board Commissioners from outside can reduce financial statement fraud. The study also shows that the size of Council and characteristic of Independent Commissioner has influence in financial statement fraud. Chtourou et al (2001) found that the Board Commissioners and audit committee are significantly related to earnings management practice. 
From the view of management accounting theory, earnings management highly determined by company's manager motivation. Jensen and Meckling (1976) show that earnings management can be minimalized by enlarging the stock ownership by the company management (managerial ownership). From the explanation above then the hypothesis research as follows.

H6a: Managerial ownership Structure significant influence on earnings management in banking industry in Indonesia.

H6b: Managerial ownership Structure significant influence on earnings management in banking industries' in China.

The Board Commissioners as a top company's internal control system has the role as supervisory activities (Siallagan and Machfoedz, 2006). In general the Board Commissioners was commissioned and given responsibility for monitoring the information quality contained in financial statements. Research Beasley (1996) concluded that the proportion of Independent Board Commissioners can reduce financial statement fraud. From the explanation above then the hypothesis as follows:

H7a: Proportion of Independent Board Commissioners significantly influence on earnings management in banking industry in Indonesia.

H7b: Proportion of Independent Board Commissioners significantly influences on earnings management in banking industry in China.

Board Commissioners size are able to give the influence on company's performance. Yu (2006) found that the size of Board Commissioners has negatively influence on earnings management. This signifies that fewer Board Commissioners then make the earnings management practice higher because of few Board Commissioners. It makes possibility for organizations to be dominated by the management to bring their roles. From the explanation the hypothesis as follows:

H8a: Size of the Board Commissioners significantly influence on earnings management in banking industry in Indonesia.

H8b: Size of the Board Commissioners significantly influence on earnings management in banking industry in China.

The audit committee will be able to reduce the earnings managements practice. Siallagan and Machfoedz (2006) found that the audit committee has positively influence to earnings and value quality of the company. From the explanation above then the hypothesis research as follows:

H9a: Size of audit committee significantly influences on earnings management in banking industry in Indonesia.

H9b: Size of audit committee significantly influences on earnings management in banking industry in China.

\section{Analysis and Discussion}

Based on the discussion of theory, research data, research variables, and previous studies, this research form the regression equation using the following model:

$$
\begin{array}{ll}
\text { Model 1: } & D A C C=\alpha+\beta_{1} M S O+\beta_{2} P B O C+\beta_{3} S B O C+\beta_{4} S A C \\
\text { Model 2: } & D A C C=\alpha+\beta_{1} M S O+\beta_{2} P B O C+\beta_{3} S B O C+\beta_{4} S A C
\end{array}
$$

Based on the analysis $\mathrm{H} 1$ is accepted, i.e. there is differentiation between earnings management in banking industry in Indonesia and China. If it is viewed from average of earnings managements two group, China's banking industry has higher earnings management than banking in Indonesia. The high of earnings management in banking industry in China due to the China Securities Regulatory Commission (CSRC) has made the rules and recommendations on Corporate Governance. CSRC presuppose to companies listed to meet the criteria for Return on Equity (ROE) reported is $6 \%$ for three consecutive years, and the average ROE over the these years must be not less than $10 \%$, and the criteria that are most important to de-listings of registered company is reporting a net loss for three consecutive years (Liu and $\mathrm{Lu}, 2007$ ). It is not an easy thing for Chinese companies to comply the regulation. Therefore, the managers will do everything that is able to avoid a net loss for these three years respectively by doing earnings management. Whereas in Indonesia during the global crisis (observation period), the banking industry is precisely able to increase revenues significantly (Colin, 2009). It has made banking industry in Indonesia do not do earnings management extremely.

$\mathrm{H} 2$ is acceptable where there is difference between managerial ownership structure on banking industry in Indonesia and China. If it is viewed from average of managerial ownership structure two groups, China's banking industry has higher managerial ownership structure than banking in Indonesia.The high of managerial ownership struc ture in China's banking basically is caused of all the companies in China adopt managerial ownership governance. The manager has a large stock in company because of China's Government issued regulations management stock incentive to set rules and encourage companies to provide stock for top management in order to reduce the agency conflict (Andy, 2012). Similarly in Indonesia, managerial ownership 
structure is utilized to reduce the agency conflict, increasing the proportion managerial stock ownership then company performance will be better. Greater stock ownership in economic terms has incentive to monitor management. Theoretically, when managerial ownership is lower, then the incentive on possibility of opportunistic management will increase. Managerial ownership on company's stock can be seen aligning potential interest differentiation between shareholders and management (Ujiyanto \& Pramuka, 2007). But in fact, managerial ownership structure in banking industry is very low so the agency conflict in company is inevitable.

H3 is acceptable where there is difference between Independent Board of Commissioners in banking industry in Indonesia and China. If viewed from the average of two proportion independent Board of Commissioners groups in banking industry in Indonesia is higher than banking in China. This is caused by the existence of independent Commissioner in Indonesia have been regulated in Decree of Jakarta Stock Exchange (JSX) directors, Number: Kep 315/JSE/06-2000 which declare that in order to make a good corporate governance, companies listed on the JSE must have an independent Commissioner which the number of proportion equal to the number of ownership by shareholder that does not have control with concern on total number of Independent Commissioner at least $30 \%$ from total number of Commissioners members.

Meanwhile, the China Securities Regulatory Commission (CSRC) in 2001 issued a regulation that Chinese companies that are listed have at least 2 Board of Commissioners which is independent and must have a basic knowledge in law and regulations in capital market field (Lai et al., 2005). The Independent Board of Commissioners should be honest and responsible, with the experience is more than 5 years working in related fields. However, it is not easy for China's enterprises to get independent Board of Commissioners in accordance with the regulations of the CSRC. Therefore the proportion independent Board of Commissioners in banking industry in Indonesia is higher than banking industry in China.

H4 is acceptable where there is difference between Board of Commissioners size on the banking industry in Indonesia and in China. If viewed from the average of two sizes of the Board of Commissioners groups in banking industry in China is higher than banking in Indonesia. This is caused by number of Board of Commissioners will influence on work efficiency. The number of Board of Commissioners that regulated by law firm in China is 5-7 people. The specific number must be determined within the framework of budget based and should be revised in the shareholders meeting. The number of Board of Commissioners is determined by company size. To be larger of the company the number of Board of Commissioners will be greater (Zhong, 2002). While in Indonesia, the number of Board of Commissioners depend on the industry in which the company will contribute to determine the type of competence that should be owned by the Board of Commissioners as a whole. Therefore the number of Board of Commissioners member is determined by the number of expertise types which is needed in the industry. The number of Board of Commissioners which is too large will make the process of searching an agreement and the process of making decisions becomes difficult (Rony, 2006). This limitation becomes the consideration in determining the number of company's Board of Commissioners members.

H5 is rejected, meaning that there is no difference between Audit Committee size in banking industry in Indonesia and China. If viewed from the average of two groups audit Committee size in banking industry in Indonesia is almost same with banking in China. The size of Audit Committee in a company has a limited effectiveness. The number of audit committee members may not exceed the number of Board of Commissioners, because the optimum effectiveness can be obtained only with a proportional Audit committee number. A small number makes weak monitoring on corporate financial statements conducted by management, while if too large causing weakness in coordinating in the Committee and less effective monitoring. In addition, the audit Committee also has consequences such as, audit opinion, restatements, and earnings management. These will become considerations for Indonesia and China's company to decide the number of audit committee number.

Regression analysis shows that managerial ownership structure in banking industry in Indonesia has negative significantly influence on earnings management, so in this research H6a can be accepted. While in China's banking data, do not influence significantly on earnings management, so in this research H6b can be rejected. Independent Board of Commissioners proportion in banking industry in Indonesia do not significantly influence on earnings management, so in this research $\mathrm{H} 7 \mathrm{a}$ can be rejected. While in China's banking data, negative significantly influence on earnings management, so in this research $\mathrm{H} 7 \mathrm{~b}$ can be accepted. Board of Commissioners size in banking industry in Indonesia positive significantly influence on earnings management, so in this research H8a can be accepted. While in China's banking data, negative significantly influence on earnings management, so in this research $\mathrm{H} 8 \mathrm{~b}$ can be accepted. Audit committee size in banking industry in Indonesia negative significantly influence on earnings management, so in this research H9a can be accepted. While in China's banking data, positive significantly influence on earnings management, so in this research $\mathrm{H} 9 \mathrm{~b}$ can be accepted.

The regression calculation result for banking industry data in Indonesia indicate that managerial ownership structure variables, independent Board of Commissioners, Board of Commissioners size and audit Committee size in banking industry in Indonesia and China simultaneously or together has influence on earnings management. 


\section{Conclusion}

Based on the research results and discussion in previous chapter can be concluded:

There is a difference between earnings management in banking industry in Indonesia and China. The average of earnings management in banking industry in China is higher than in Indonesia.

There is a difference between managerial ownership structure in banking industry in Indonesia and China. The average of managerial ownership structure in banking industry in China is higher than in Indonesia. However, based on hypothesis managerial ownership structure test result in banking in China negative significantly influence on earnings management, while in banking in Indonesia shows that managerial ownership structure has no significantly influence on management.

There is a difference between proportion independent Board of Commissioners in banking industry in Indonesia and China. The average proportion independent Board of Commissioners in banking industry in Indonesia is higher than in China. However, based on the hypothesis test result, showed that the proportion independent Board of Commissioners in banking industry in Indonesia has no significantly influence on earnings management practices, while in China's banking, proportion independent Board of Commissioners variable has negative significantly influence on earnings management.

There is a difference between Board of Commissioners size in banking industry in Indonesia and China. The average of Board of Commissioners size in banking industry in China is higher than in Indonesia. However, based on hypothesis test result is showed that Board of Commissioners size in banking industry in Indonesia is positive significantly influence on earnings management, while in China's banking shows that Board of Commissioners size has negative significantly influence on earnings management.

There is no difference between Audit Committee size in banking industry in Indonesia and China. The average of Audit Committee size in banking industry in Indonesia is almost same with China's banking. Based on hypothesis test result is showed that Audit Committee size in banking industry in Indonesia negative significantly influence on earnings management, while in China's banking data is showed that audit committee size is positive significantly influence on earnings management.

\section{References}

- Andy. 2012. "Correlation Comparison of Managerial Ownership and Company Performance between Before and After Reform of the Shareholder Structure." Economic Paper.

- Beasley, M. 1996. An Empirical Analysis of The Relation Between The Board of Director Compensation and Financial Statement Fraud. The Accounting review, vol. 71, pp. 443-465.

- Capital Market Supervisory Agency. 2004. "Pembentukan dan Pedoman Kerja Komite Audit." Kep29/PM/2004.

- Chen, Xin. and Nan Zhou. 2009. “Audit Committee Effectiveness: Evidence From a Government Inspection in China.” Working paper. University Jiaotong.

- Chtourou, S.M., Bedard, J. and Courteau, L. 2001. Corporate governance and earnings Management. working paper. University of Laval Canada.

- Cornett, et.al. 2006. "Earnings Management, Corporate Governance and True Financial Performance." Working Paper Series.

- $\quad$ Daniel, Wahyu. 2010. Industri Perbankan RI Terus Melaju Pasca Krisis. Detik Finance.Available:http://www.detikfinance.com.

- Dechow, Patricia M., R.G. Sloan and A.P. Sweeney. 1995. "Detecting earnings management." The Accounting Review 70. 193-225.

- $\quad$ Ding Y., Zhang H., Zhang J.X. 2004. “ Ownership Concentration and Earnings Management: A Comparison Between Chines Private and State-Owned Listed Companies”. Research in Accounting Conference. 4-6 July 2004. Singapore.

- Ghozali, Imam. 2006. Aplikasi Analisis Multivariate dengan Program SPSS. Semarang: Badan Penerbit Universitas Diponegoro.

- Gideon. 2005. "Kualitas Laba: Studi Pengaruh Mekanisme Corporate Governance dan Dampak Manajemen Laba dengan Menggunakan Analisis Jalur.” Simposium Nasional Akuntansi 8. Solo.

- Hongkong Stock Exchange. Laporan Keuangan Tahunan Perusahaan Perbankan Go Publik Tahun 2006, 2007, 2008, 2009. Available: http://www. hkex.com. hk.

- Ikatan Akuntan Indonesia. 2002. Statement of Financial Accounting Standard. Salemba Empat. Jakarta. 
- Indonesia Stock Exchange. Laporan Keuangan Tahunan Perusahaan Perbankan Go Publik Tahun 2006, 2007, 2008, dan 2009. Available: http://www.idx.co.id.

- Jennings, M. M. 2005. "Conspicuous Governance Failures: Why Sarbanes-Oxley Is not an Ethics Warranty.” Corporate Finance Review, 9:5 (Maret/April).

- Jensen and Meckling. 1976. "Theory of The Firm: Managerial Behavior, Agency and Ownership Structure." Journal of Financial Economic. Vol. V 3, No.4.

- Komite Nasional Kebijakan Governance. 2006. Pedoman Umum Good Corporate Governance Indonesia. http:/www.google.com, Access: January $22^{\text {th }} 2012$.

- $\quad$ Lai, L. and Tam, H. .2005. "Independent directors and the propensity to smooth earnings: a study of corporate governance in China”, The Business Review, Vol. 7 No. 1, pp. 328-335.

- $\quad$ Liu, Q. and Lu, Z. .2007. “Corporate governance and earnings management in the Chinese listed companies: A tunneling perspective,” Journal of Corporate Finance, Vol. 13 No. 5, pp. 881-906.

- Midiastuti, Pranata P., and M. Machfoedz. 2003. “Analisis Hubungan Mekanisme Corporate Governance dan Indikasi Manajemen Laba." Simposium Nasional Akuntansi (SNA) VI. Surabaya.

- Nasution, Marihot dan Doddy Setiawan. 2007. "Pengaruh Corporate Governance Terhadap Manajemen Laba Di Industri Perbankan”. Simposium Nasional Akuntansi X, IAI, Makasar.

- Nurhayati, Mafizatun. 2006. “Analisis Data Uji Beda T-Test.” Metode Penelitian. Fakultas Ekonomi.Universitas Mercubuana. Jakarta.

- Rahmawati, et al. 2006. "Pengaruh Asimetri Informasi terhadap Praktik Manajemen Laba pada Perusahaan Perbankan Publik yang terdaftar di Bursa Efek Jakarta.” Simposium Nasional Akuntansi IX.

- $\quad$ Rony, Kusuma Muntoro. 2006. “Membangun Dewan Komisaris yang Efektif.” Working Paper Series.

- $\quad$ Scott, William R. 2000. Financial Accounting Theory. $2^{\text {nd }}$ Ed. Prentice Hall Inc. Ontorio. Canada.

- Setiawati, L., and Naim. 2001. "Manajemen Laba.” Jurnal Ekonomi dan Bisnis Indonesia. Vol. 15, No. 4, hal. 424-441.

- Shi, S. and Weisert, Drake. 2002 'Corporate governance with Chinese characteristics', The China Business, 29:12-19.

- $\quad$ Siallagan, H., dan M. Machfoedz. 2006. Mekanisme Corporate Governance, Kualitas Laba dan Nilai Perusahaan. Simposium Nasional Akuntansi (SNA) IX Padang.

- Surya, Indra dan Yustiavandana, Ivan. 2008. Penerapan Good Corporate Governance. Jakarta: Kencana Prenada Media Group.

- Ujiyanto, Moh. Arief and Bambang A Pramuka. 2007. "Mekanisme Corporate Governance, Manajemen Laba dan Kinerja Keuangan.” Simposium Nasional Akuntansi X.

- Watts, R. L., and J.L. Zimmerman. 1989. Positive Accounting Theory. Englewood Cliffs, NJ: PrenticeHall, Inc., 1989.

- Xie, B., Davidson III, W.N. and DaDalt, P.J. 2003. "Earnings Management and Corporate Governance: the Role of the Borad and the Audit Committee", Journal of Corporate Finance, Vol. 9 No. 3, pp. 295-316.

- Yermack, D., 1996. Higher market valuation of companies with a small board of directors. Journal of Financial Economics, 40, 185a. 211.

- Yu, Q., Du, B., and Sun, Q. 2006. "Earnings management at rights issues thresholds - evidence from China", Journal of Banking and Finance, Vol. 30 No. 12, pp. 3453-3468.

- Zhong, Jiyin. 2002. "Board of Director: Composition, Meeting and Committee." Research Fellow Institute of Economics. Chinese Academy of Social Sciences. 